\title{
Clinical and biological aspects of aggressive B-cell non-Hodgkin lymphoma in adolescents and young adults
}

This article was published in the following Dove Press journal:

Clinical Oncology in Adolescents and Young Adults

30 November 2015

Number of times this article has been viewed

\section{Diane Coso \\ Sylvain Garciaz \\ Réda Bouabdallah \\ Department of Hematology, Cancer Center Institut J. Paoli-I. Calmettes, University of La Méditerranée, Marseille, France}

\begin{abstract}
Non-Hodgkin lymphomas (NHLs) are one of the most frequent malignancies in adolescents and young adults (AYA). Among NHLs, Burkitt's lymphoma (BL) represents approximately $40 \%$ while diffuse large B-cell lymphoma (DLBCL) accounts for nearly $20 \%$ of cases. Primary mediastinal B-cell lymphoma is a variant of DLBCL, which preferentially concerns young patients. Biology of B-NHLs is well known and several pathways involving chromosomal translocations, gene rearrangements, and molecular profiling are the subject of continuous investigations. AYA with B-NHL have inferior survival when compared with children. The reasons for this unfavorable outcome are multifactorial, but disease-related biological characteristics of the tumor represent a powerful factor influencing survival. The choice of optimal strategy in the management of B-NHL in patients of 15-29 years old remains controversial and depends on the treating institution and its physicians. Although children and younger adolescents benefit from pediatric approaches using intensive treatment, older adolescents are often treated with adult rituximab-based chemotherapy. In this review, we focus on the current knowledge relevant to AYA with DLBCL and primary mediastinal B-cell lymphoma.
\end{abstract}

Keywords: DLBCL, PMBCL, AYA, prognosis, treatment

\section{Introduction}

Adolescence, considered as the age between 15 and 20 years, and young adulthood from 20 to 30 years have become the focus of basic and clinical investigation in cancer in recent years. In developed countries, non-Hodgkin lymphoma (NHL) is the second most frequent malignancy and represents approximately $10 \%-12 \%$ of all cancers diagnosed among adolescents and young adults (AYA). NHLs in AYA are mostly of $B$ phenotype. In contrast to younger patients in whom Burkitt's lymphoma (BL) and lymphoblastic lymphoma (LBL) are the commonest variants, the major histological subtype among adolescents consists in diffuse large B-cell lymphoma (DLBCL). Among DLBCL, primary mediastinal B-cell lymphoma (PMBCL) is recognized as a distinct entity and readily occurs in AYA, and represents $6 \%$ of patients. ${ }^{1-3}$ Other histological subtypes among adolescents were reported from French and German cooperative groups with the following frequencies: BL $22 \%-27 \%$, anaplastic large cell lymphoma (ALCL) 18\%-20\%, and LBL 15\%-17\% (Figure 1). ${ }^{4,5}$

The risk of developing NHL progressively increases with age. However, the incidence also varies by sex and racial subgroup. The Surveillance, Epidemiology and End Results registry from 1975 to 2000 reported an age-adjusted rate of NHL between 1.8 and 3.2/100,000 among 16- to 30-year-old patients, while this rate substantially increased in patients aged above 31 years $(5.2-38 / 100,000)$. Usually, males develop 


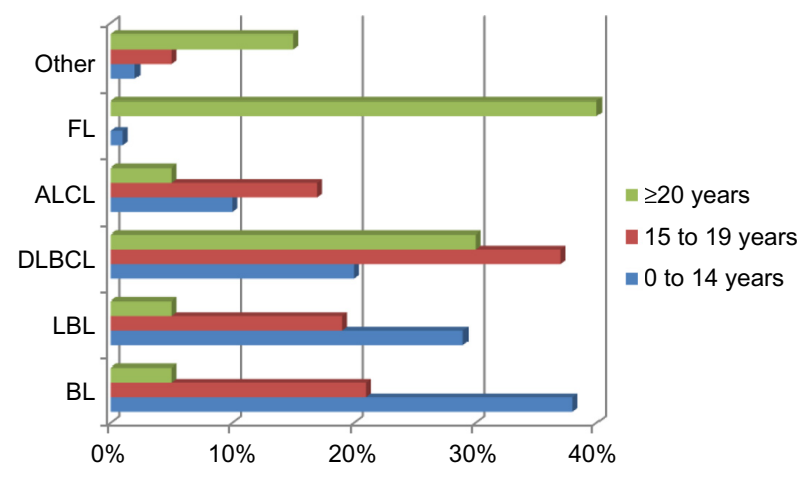

Figure I Incidence of NHL subtypes according to age.

Abbreviations: ALCL, anaplastic large cell lymphoma; BL, Burkitt's lymphoma; DLBCL, diffuse large B-cell lymphoma; FL, follicular lymphoma; LBL, lymphoblastic lymphoma; NHL, non-Hodgkin lymphomas.

NHL more frequently than females, even if the overall increase rate of NHL over the last 15 years has been seen principally in the female population. ${ }^{6,7}$

Although causes of NHL in AYA are still unknown, several risk factors have been suggested to play a role in the development of NHL. Immunodeficiency syndromes, HIV infection, immunosuppressive therapies, Epstein-Barr virus and Helicobacter pylori infection, organ transplantation, and chemical exposure are usually cited in the literature. ${ }^{7}$

Inferior survival has been demonstrated in AYA in comparison with children with a 5-year overall survival (OS) of $75 \%$ and $85 \%$, respectively. ${ }^{1,8,9}$ In the same way, the results of the Lymphome Malin B 89 (LMB 89) study have demonstrated a significant increased risk of relapse in patients of 15 years of age or older. ${ }^{8}$ Many factors may contribute to these age-related differences. Review of clinical trials and outcomes has shown that US pediatric patients less than 15 years old are mainly treated on National Cancer Institute sponsored trials, while older population is rather treated at the discretion of the treating institution. ${ }^{10}$ Thus, children compared with adolescents tend to have better OS at the end of treatment. AYA are positioned between children and adult population. These findings raise the question of the choice of treatment in the AYA population: what is the best choice between pediatric or adult's protocols in the treatment of mature B-cell lymphomas? A similar problem in the management of AYA is raised in acute lymphoblastic leukemia. Some retrospective studies have been published in this setting and showed a better outcome for AYA treated with pediatric protocols. ${ }^{11-13}$ However, regarding NHL, currently there is no data suggesting a benefit from pediatric approaches or from adult rituximab-based chemotherapy. The optimal strategy in the management of DLBCL and PMBCL in patients of 15-29 years old is controversial and has probably to be directed by the identification of prognostic factors including biology, genetic, and clinical features. In this systematic review, we focus on the current knowledge relevant to AYA with DLBCL and PMBCL.

\section{Biological features}

DLBCL is a heterogeneous group of rapidly growing tumors characterized by a diffuse infiltrate of medium to large cells that alters the lymph-node architecture. Based on the World Health Organization (WHO) NHL classification, morphologic variants have been described and centroblastic variant is the most common. However, immunophenotyping is absolutely necessary to distinguish different subtypes, as well as other type of NHL especially BL. DLBCL expresses pan-B-cell markers CD19, CD20, CD22, and CD79a. The proliferation index $\mathrm{Ki}-67$ is usually $>90 \%$ in $\mathrm{BL}$, but it is not uncommon for DLBCL to show very high proliferation rate. ${ }^{14}$

Unlike BL that carries typical translocation of the c-myc oncogene $\mathrm{t}(8 ; 14)$ (or $\mathrm{t}[8 ; 22]$ [q24;q11] or $\mathrm{t}[2 ; 8]$ [p12;q24]), there are no defining cytogenetic abnormalities for DLBCL. However, 5\%-10\% of DLBCL can express $c-m y c$ rearrangements. Another confounding factor is that both DLBCL and BL can express CD10 and Bcl-6 associated with germinal center derivation, and lack expression of terminal deoxynucleotidyl transferase which is expressed by LBL cells. ${ }^{15}$ Another category has been identified as Burkitt-like lymphoma or atypical BL, or B-cell lymphoma unclassifiable with features intermediate between DLBCL and BL. This subgroup has morphological and genetic features of both DLBCL and BL but should not be included in these categories. These NHL are relatively rare and are clinically and biologically distinct from both conventional DLBCL and BL. They frequently have a germinal center phenotype (CD20+, Bcl6+, and $\mathrm{CD} 10+)$, myc rearrangements, and a high proliferation rate as described in BL. However, they show some differences with BL such as Bcl2 protein expression. ${ }^{16,17}$

Based on gene expression profiling (GEP), two major subgroups of DLBCL have been identified in adults: germinal center B-cell-like (GC) DLBCL and activated B-cell-like (ABC) DLBCL. ${ }^{18-21}$ This molecular signature predicts an independent outcome of the international prognostic index (IPI) score. The GC signature confers a favorable outcome with a 5 -year OS of 76\%, while patients with non GC-DLBCL have a 5-year OS of $34 \%$. A routine immunohistochemistry test can be used to differentiate the GCB and the ABC phenotype by correlating expression of CD10 and bcl-6 which are the markers of germinal center, and expression of the 
post germinal center marker MUM1. Expression of MUM1 is often associated with the $\mathrm{ABC}$ phenotype. ${ }^{22}$

The GCB phenotype is more frequent in pediatric population and probably influences the favorable outcome in children. Thus, as well as in adult population, expression of GC signature tends to a favorable outcome. However, approximately $20 \%$ of children are diagnosed with the ABC subtype and do not show a worse outcome. ${ }^{23}$ Furthermore, the GCB subtype frequently presents with chromosomal translocations juxtaposing the IRF4 oncogene next to one of the immunoglobulin (Ig) loci in children and AYAs. Although IRF4 translocation seems to confer a better outcome, such advantage appears moderate in an age-adjusted analysis. ${ }^{24}$

When comparing GEP of BL with GEP of DLBCL, results showed that $\mathrm{ABC}$ genes expression is mostly involved in the anti-apoptotic NF- $\mathrm{\kappa B}$ signal transduction pathway with the expression of target genes as $B c l-2$ and cycline D2 conferring a bad prognosis. In the same way, $c-m y c$ and its target genes are preferentially highly expressed in BL..$^{25,26}$ Thus, using GEP, up to $31 \%$ of pediatric DLBCL cases could be reclassified as molecularly BL (mBL). ${ }^{27}$ GEP was also performed in adults' samples and only $3 \%$ of cases were reclassified as $\mathrm{mBL}$. Combining the data for $\mathrm{mBL}$ in adults and children, no significant differences in immunophenotype, gene expression, genetic aberration, or survival were found between pediatric and adult population. Recent studies also suggest that rearrangement of $c-m y c$ occurring in up to $5 \%-10 \%$ of patients with DLBCL confers a very poor prognosis particularly when it is associated with rearrangement of bcl-2, a condition referred as double-hit DLBCL. ${ }^{28}$ This abnormality has become a powerful prognostic factor of negative outcome in patients treated with R-CHOP (rituximab, cyclophosphamide (CPM), doxorubicin (DXR), vincristine (VCR), and prednisone) with a 5-year OS not exceeding $30 \%{ }^{28,29}$ Similar outcome is described in children and adolescent with doublehit lymphomas. ${ }^{27}$

Summarizing, pediatric DLBCL is characterized by moderate to high proliferation rates, increased $c$-myc expression, decreased bcl-2 expression, and predominant GC subtype when compared with adults DLBCL. A high molecular homogeneity among adults and pediatric GCDLBCL cases has been reported, but no molecular marker to distinguish pediatric from adult DLBCL could be identified. ${ }^{30}$ Furthermore, a cutoff value for biological features to discriminate adult and pediatric DLBCL has been evaluated. Markers included ABC subtype, translocation affecting bcl6 locus, bcl-2 protein expression, Ig/IRF4 translocations, and additional chromosome aberrations. The highest increase in genetic variation was observed in patients between 25 and 40 years of age. When statistically adjusted for age, genetic complexity, and specific genetic markers, no relevant prognostic impact could be identified. Thus, no clear biological cutoff could be determinate, except ABC subtype that remains a pejorative prognostic factor in advanced age. ${ }^{31}$

Primary mediastinal B-cell lymphoma is a distinct entity recognized by the WHO NHL classification. ${ }^{17} \mathrm{PMBCL}$ is a rare disease issued from mature thymic B-cells characterized by a diffuse proliferation of large cells and sclerosis. Lymphoma cells are more pleomorphic and may look like Reed-Sternberg cells. In contrast to classical Hodgkin lymphoma (cHL), PMBCL cells express CD19, CD20, CD79a, and $\mathrm{CD} 23 . \mathrm{CD} 30$ typically expressed in $\mathrm{cHL}$ is frequently detected. Most patients with PMBCL presented with mutation of bcl-6 usually along with somatic mutations in the immunoglobulin heavy-chain gene, suggesting late-stage germinal center differentiation. Unlike other DLBCL, PMBCL involves defective immunoglobulin production despite the expression of the B-cell transcription factors OCT-2, BOB.1, and PU.1. ${ }^{32}$ Gains of chromosome 9p (including JAK2, PDL1, and PDL2) are present in up to $75 \%$ of patients, and gains of $2 p$ (including REL and bcl-11a) in up to $50 \%$. Gains of the same region are also highly recurrent in cHL. Other similarities between PMBCL and cHL have been highlighted using molecular profiling and especially the NF- $\kappa$ B pathway activation, suggesting that there is a close biological relationship between these two diseases. ${ }^{20,21}$

Otherwise, a new biological entity designed as mediastinal gray zone lymphoma (MGZL) has been recognized by the WHO classification. MGZL shares transitional features between PMBCL and cHL. While morphology is compatible with the diagnosis of PMBCL, the immunophenotype shows features of $\mathrm{cHL}$ such as positivity for CD15 or EBER. A recent retrospective biological study of the Berlin-Frankfurt-Munster (BFM) group reported the rarity of MGZL in children and adolescents and showed a worse prognosis when compared with PMBCL. ${ }^{33}$

\section{Clinical features Clinical presentation}

DLBCL and BL share clinical and biological features in children and adolescents aged from 15 to 19 years. DLBCL and BL usually arise in Waldeyer's ring and abdomen with often compressive masses, whereas peripheral lymph nodes are less commonly involved, more likely in DLBCL than in BL. Data issued from the BFM experience are underlying principal clinical differences. ${ }^{15}$ DLBCL is mostly localized 
disease with approximately half patients with St Jude stage I/II (Table 1). Central nervous system (CNS) and bone marrow (BM) are rarely involved in DLBCL patients. Ascites is more likely diagnosed in patients with BL. Elevated serum lactate dehydrogenase (LDH) levels are also more frequent in BL patients.

PMBCL characteristically presents with a large mediastinal tumor involving adjacent mediastinal structures and often accompanied by superior vena cava syndrome and obstruction of the upper airways. PMBCL patients are predominantly female and often present with associated pleural and/or pericardial effusion. Lung involvement occurs in approximately $30 \%$ of patients. Abdominal structures are rarely involved. The most frequent extra thoracic manifestations are kidney tumors. B symptoms and elevated LDH levels are frequent, and present in more than a third of patients. CNS is never quite positive. ${ }^{34}$

\section{Diagnosis and staging}

The diagnosis of NHL needs to be confirmed by lymph-node biopsy. But, in some cases, cytological examination and flow cytometry of malignant effusion and/or BM smears may be a valuable alternative for diagnosis, especially in case of anesthetic risk due to a large mediastinal mass. However, in PMBCL the BM is almost invariably negative and effusions frequently do not contain malignant cells.

The standard morphology, flow cytometry, and immunohistochemical evaluation of the tumor are sufficient in the majority of cases in order to assess diagnosis. Confirmation

Table I St Jude's (Murphy) staging system

\begin{tabular}{ll}
\hline Stage & Description \\
\hline I & A single tumor (extranodal) or a single anatomic area \\
(nodal) with the exclusion of the mediastinum or abdomen & A single extranodal tumor with regional node involvement \\
& Two single extranodal tumors on the same side of the \\
& diaphragm with or without regional node involvement \\
& Primary gastrointestinal tumor with or without involvement \\
& of associated mesenteric nodes only \\
IIR & Completely resected intra-abdominal disease \\
III & Two single extranodal tumors on opposite sides of the \\
& diaphragm \\
& All primary intrathoracic tumors (mediastinal, pleural, thymic) \\
& All paraspinal or epidural tumors regardless of other tumor site \\
& All extensive primary intra-abdominal disease \\
IIIA & Two or more nodal areas on opposite sides of the diaphragm \\
IIIB & Localized/unresectable intra-abdominal disease \\
IV & Widespread multi-organ abdominal disease \\
& Any of the above with initial CNS and or bone marrow \\
& involvement ( $>25 \%$ involvement is defined as acute \\
& lymphoblastic leukemia)
\end{tabular}

Abbreviation: CNS, central nervous system. by a central reference laboratory should be done whenever possible. Cytogenetic and molecular characterizations of the tumor are highly recommended especially to differentiate BL from DLBCL with the characterization of $t(8-14)$ or expression of c-myc. These tests are commonly performed in clinical trials, and they are highly suitable in practical routine.

Standard biological evaluation requires differential blood count, coagulation, chemistry including LDH levels, BM, and virus serologies including HIV, Epstein-Barr virus, and hepatitis. The cerebrospinal fluid evaluation is invariably indicated in patients treated with pediatric approaches, while recommendations concern mainly high-risk patients and/ or patients with neurological clinical symptoms in adult population.

Standard imaging studies including ultrasound, radiography of the chest, computed tomography (CT) scan, and magnetic resonance imaging are widely used to determine disease extent in children and adolescents. In order to limit the radiation exposure, CT scan is not routinely used. To date, the F-fluorodeoxyglucose-positron emission tomography (FDG-PET/CT) is probably the most critical examination used in DLBCL adult patients and is highly recommended both at baseline and at the end of treatment. ${ }^{35}$ It is not part of routine staging in pediatric and adolescent patients except in clinical trials. FDG-PET/CT may represent a helpful tool in evaluating residual masses especially in PMBCL and may provide additional role in initial staging. ${ }^{36}$ Further studies are needed in this population.

Staging is usually based on St Jude classification also called Murphy stage in pediatric population, whereas Ann-Arbor classification is widely used for adults (Tables 1 and 2)..$^{37,38}$

\section{Table 2 Ann-Arbor staging}

\begin{tabular}{ll}
\hline Stage & Description \\
II & $\begin{array}{l}\text { Involvement of a single lymph-node region (I) or of a single } \\
\text { extralymphatic organ or site (IE) } \\
\text { Involvement of two or more lymph-node regions on the } \\
\text { same side of the diaphragm or localized involvement of an } \\
\text { extralymphatic organ or site of one or more lymph node } \\
\text { regions on the same side of the diaphragm (IIE) } \\
\text { Involvement of lymph-node regions on both sides of the } \\
\text { diaphragm, which may also be accompanied by localized } \\
\text { involvement of extralymphatic organs or site (IIIE) or by } \\
\text { involvement of the spleen (IIIS) or both (IIISE) } \\
\text { Diffuse or disseminated involvement of one or more } \\
\text { extralymphatic organs or tissues with or without associated } \\
\text { lymph-node enlargement } \\
\text { Unexplained weight loss of more than I0\% of the body } \\
\text { weight in the } 6 \text { months prior } \\
\text { Unexplained fever with temperature }>38^{\circ} \\
\text { Night sweats }\end{array}$ \\
\hline
\end{tabular}




\section{Prognostic factors}

Several clinical and biological factors have been tested as prognostic markers in B-NHL (Table 3). The purpose was to elaborate a prognostic index able to predict response to treatment and survival. Based on the previous LMB 89 study, the French-American-British/LMB (FAB/LMB) has defined three risk groups receiving progressive intensive treatment according to tumor resection status and BM or CNS involvement. ${ }^{8}$ The BFM group has also provided a stratification integrating LDH levels. ${ }^{34,39}$ Furthermore, clinical adverse factors leading to a significant inferior survival have been published. These include advanced stage, age $>15$ years, elevated LDH, primary mediastinal involvement, and combined BM/CNS disease. ${ }^{40}$ In adults and since the 1990s, the age-adjusted International Prognostic Index (aa-IPI) represents the most powerful prognostic index. The aa-IPI is evaluated at diagnosis and is based on performance status, $\mathrm{LDH}$ value, and extent of disease according to the Ann-Arbor classification. The resulting score identifies four prognostic groups with significant differences in complete response rate to chemotherapy and OS. ${ }^{41}$ The aa-IPI has not been validated in pediatric population and is usually not

Table 3 Risk factors classification

\begin{tabular}{|c|c|c|}
\hline $\begin{array}{l}\text { French-American- } \\
\text { British (FAB) }\end{array}$ & $\begin{array}{l}\text { Berlin-Frankfurt- } \\
\text { Munster (BFM) }\end{array}$ & $\begin{array}{l}\text { Age-adjusted } \\
\text { international } \\
\text { prognostic } \\
\text { index (IPI) }\end{array}$ \\
\hline & & $\begin{array}{l}\text { Risk factors } \\
\text { Stage Ann-Arbor III-IV } \\
\text { LDH }>N \\
\text { PS } \geq 2\end{array}$ \\
\hline $\begin{array}{l}\text { Group A } \\
\text { Resected stage I and } \\
\text { abdominal completely } \\
\text { resected stage II }\end{array}$ & $\begin{array}{l}\text { RI } \\
\text { Stage I or II } \\
\text { completely resected }\end{array}$ & $\begin{array}{l}\text { Low risk } \\
\mid \mathrm{IPI}=0\end{array}$ \\
\hline $\begin{array}{l}\text { Group B } \\
\text { All patients not in } \\
\text { Group A or C }\end{array}$ & $\begin{array}{l}\mathbf{R 2} \\
\text { Stage I or II not } \\
\text { resected } \\
\text { Stage III with LDH } \\
<500 \text { IU/L }\end{array}$ & $\begin{array}{l}\text { Low/intermediate } \\
\text { risk } \\
I P I=I\end{array}$ \\
\hline & $\begin{array}{l}\text { R3 } \\
\text { Stage III with LDH } \\
\geq 500 \text { to }<\mathrm{I}, 000 \mathrm{IU} / \mathrm{L} \\
\text { Stage IV with } \mathrm{LDH} \\
<\mathrm{I}, 000 \mathrm{IU} / \mathrm{L} \text { and } \\
\text { CNS negative }\end{array}$ & $\begin{array}{l}\text { High/intermediate } \\
\text { risk } \\
I \mathrm{II}=2\end{array}$ \\
\hline $\begin{array}{l}\text { Group C } \\
\text { Bone marrow disease } \\
\text { ( } \geq 25 \% \text { L3 blasts) and } \\
\text { or CNS positive }\end{array}$ & $\begin{array}{l}\text { R4 } \\
\text { Stage III or IV with } \\
\text { LDH } \geq I, 000 \text { IU/L } \\
\text { and/or CNS positive }\end{array}$ & $\begin{array}{l}\text { High risk } \\
I P I=3\end{array}$ \\
\hline
\end{tabular}

Abbreviations: CNS, central nervous system; LDH, lactate dehydrogenase; PS, performance status. used in children. One of the most important prognostic factors is the patient's response to therapy. A failure to initial chemotherapy significantly affects survival in children and adolescents especially those with advanced stages. ${ }^{8}$ Although these prognostic indexes are still routinely used for therapeutic decisions, they are probably less effective because of all new biological and radiological technologies, and changes may be necessary.

\section{Treatment and prognosis Diffuse large B-cell lymphoma} Pediatric approach

Adolescents and children's DLBCL and BL are usually treated with similar chemotherapy approach without any distinction. The treatment is based on the concept of highdose intensity chemotherapy regimen and consists of two to eight chemotherapy courses including intrathecal treatment. The most widely used drugs are high-dose methotrexate (HDMTX), high-dose cytarabine (Ara-C), and CPM, combined with corticosteroids, VCR, etoposide (ETO), and DXR. Intrathecal chemotherapy (ITC) is preferentially reserved for intermediate and high-risk patients.

Results of large pediatric cooperative trials over the last three decades have reported an increase in event-free survival (EFS) in pediatric patients, ranging from $80 \%$ to $99 \%$. Due to these results, trials were then established with tailored chemotherapy according to patient's risk factors (Table 3). The aims of these trials were to decrease long-term toxicities in favorable prognosis patients, and to intensify treatment in poor-risk patients. The two major contributive studies have been provided by the FAB/LMB and the BFM groups. Other groups have adapted or refined these strategies into their own protocols. Patients were allocated to risk groups according to stratification criteria, and treatment intensity was adapted according to the risk of relapse. Results of the studies are summarized in Table 4.

The FAB/LMB 96 was a large international cooperative study that investigated the impact of reducing intensity of treatment in this young population. Three risk groups have been defined (Table 3). Patients with low-risk B-NHL group A (10\% of patients) have an excellent survival with a $98.3 \%$ 4-year EFS when treated with two courses of COPAD (CPM, VCR, DXR, prednisone) without ITC. ${ }^{42}$

Patients with intermediate risk B-NHL group B (70\% of patients) received first a prephase with COP (low-dose CPM, VCR, and prednisone), and were evaluated at day 7 . Early-responding patients received the first induction course COPADM1 (CPM $1.5 \mathrm{~g} / \mathrm{m}^{2}$, oncovin, prednisone, DXR, 
Table 4 DLBCL selected studies including AYA patients

\begin{tabular}{|c|c|c|c|c|c|c|}
\hline Reference & No of patients & Disease & Age & Treatment & Outcome & Comments \\
\hline Gerrard et al ${ }^{42}(p)$ & $\begin{array}{l}23 \text { patients } \\
\text { aged } \geq 15 \text { years } \\
\text { (total } n=140 \text { ) }\end{array}$ & $\begin{array}{l}\text { Mature B-cell } \\
\text { lymphoma } \\
\text { (DLBCL: } 43 \%)\end{array}$ & $\begin{array}{l}\text { Median I0.3 } \\
\text { (range I.8-20) }\end{array}$ & $\begin{array}{l}\text { FAB/LMB } 96 \\
\text { Risk Group A }\end{array}$ & $\begin{array}{l}4 \text {-year EFS } 98.3 \% \\
4 \text {-year OS } 99.2 \%\end{array}$ & Median FU: 50.5 months \\
\hline Patte et $\mathrm{al}^{43}(\mathrm{p})$ & $\begin{array}{l}\text { I02 patients } \\
\text { aged } 15-2 \mid \text { years } \\
\text { (total } n=637 \text { ) }\end{array}$ & $\begin{array}{l}\text { Mature B-cell } \\
\text { lymphoma }\end{array}$ & $\begin{array}{l}\text { Median } 10.2 \\
\text { (range 2.5-20.5) }\end{array}$ & $\begin{array}{l}\text { FAB/LMB } 96 \\
\text { Risk Group B }\end{array}$ & $\begin{array}{l}4 \text {-year EFS } 92.2 \% \\
4 \text {-year OS } 94.6 \%\end{array}$ & Median FU: 54 months \\
\hline Cairo et $\mathrm{al}^{44}(\mathrm{p})$ & $\begin{array}{l}27 \text { patients } \\
\text { aged } 15-19 \text { years } \\
\text { (total } n=235 \text { ) }\end{array}$ & $\begin{array}{l}\text { Mature B-cell } \\
\text { lymphoma/ALL }\end{array}$ & & $\begin{array}{l}\text { FAB/LMB } 96 \\
\text { Risk Group C }\end{array}$ & $\begin{array}{l}4 \text {-year EFS } 79 \% \\
4 \text {-year OS } 82 \%\end{array}$ & \\
\hline Atra et al ${ }^{45}(p)$ & 112 & $\begin{array}{l}\text { Mature B-cell } \\
\text { lymphoma }\end{array}$ & $\begin{array}{l}\text { Median } 8.3 \\
\text { (range 4-19) }\end{array}$ & $\begin{array}{l}\text { UKCCSG9002 } \\
\text { (=LMB84) }\end{array}$ & $\begin{array}{l}\text { EFS } 83.7 \% \\
\text { OS } 87 \%\end{array}$ & $\begin{array}{l}\text { Median FU: } 48 \text { months } \\
\text { Murphy stage III or IV }\end{array}$ \\
\hline Pillon et $\mathrm{al}^{46}(\mathrm{p})$ & $\begin{array}{l}45 \text { patients } \\
\text { aged } 10-15 \text { years } \\
\text { (total } n=144 \text { ) }\end{array}$ & $\begin{array}{l}\text { Mature B-cell } \\
\text { lymphoma } \\
\text { (DLBCL: 39) }\end{array}$ & & AIEOP LNH92 & $\begin{array}{l}\text { EFS } 81.8 \% \\
\text { OS } 89.4 \%\end{array}$ & $\begin{array}{l}\text { Median FU: } 6.23 \text { years } \\
\text { Children }<15 \text { years were } \\
\text { eligible }\end{array}$ \\
\hline Burkhardt et al $\left.\right|^{5}(\mathrm{p})$ & $\begin{array}{l}55 \text { patients } \\
\text { aged } 15-18 \text { years } \\
\text { (total } n=378 \text { ) }\end{array}$ & $\begin{array}{l}\text { Mature B-cell } \\
\text { lymphoma } \\
\text { (DLBCL: } 55)\end{array}$ & & NHL-BFM & $\begin{array}{l}5 \text {-year EFS } 79 \% \\
5 \text {-year OS } 86 \%\end{array}$ & $\begin{array}{l}\text { Median FU: } 4.4 \text { years } \\
\text { Female outcome is worse } \\
\text { with } 5 \text {-year EFS } 71 \%\end{array}$ \\
\hline Pfreundschuh et al ${ }^{49}$ (a) & 413 patients & DLBCL & $\begin{array}{l}\text { Median } 47 \\
\text { (range 36-55) }\end{array}$ & $\begin{array}{l}\text { MinT trial } \\
\text { Patients with } \\
\text { aa-IPI 0-I }\end{array}$ & $\begin{array}{l}6 \text {-year EFS } 74 \% \\
6 \text {-year OS } 90 \%\end{array}$ & $\begin{array}{l}\text { Phase III results presented } \\
\text { for R-CHOP arm }\end{array}$ \\
\hline
\end{tabular}

Notes: (p): pediatric oncology study group; (a): adult's oncology study group.

Abbreviations: ALL, acute lymphoblastic leukemia; AYA, adolescents and young adults; DLBCL, diffuse large B-cell lymphoma; EFS, event-free survival; FAB/LMB, FrenchAmerican-British/Lymphomes Malins B; FU, follow-up; OS, overall survival; R-CHOP, rituximab, cyclophosphamide, doxorubicin, vincristine, and prednisone; UKCCS, United Kingdom Children's Cancer Study Group.

and HDMTX $3 \mathrm{~g} / \mathrm{m}^{2}$ ), and the second induction course (COPADM2) was delivered after hematological recovery. Then, they received two consolidation courses with HDMTX and high-dose Ara-C, and the treatment was concluded with one maintenance course M1 (CPM, VCR, DXR, and prednisone). In this trial and in order to evaluate the possibility of reducing the intensity of the treatment, there was a randomization after the first COPADM leading to four treatments arms: two receiving half-dose CPM in the second induction course (COPADM2) and two not receiving the maintenance course. ITC was administered throughout each cycle. The 4-year EFS was $93.4 \%$ and $90.9 \%$ in the groups with full-dose and half-dose of CPM $(P=0.40)$ and $91.9 \%$ and $92.5 \%$ in the groups with and without maintenance with no statistical difference. There was no interaction between the two treatment reductions or histologic subtypes (DLBCL/ BL). Thus, the intermediate-risk B-NHL patients who have an early response and achieve a complete remission after the first consolidation course can be cured with reduced treatment. In this analysis, the population was mainly represented by children with a median age at 10 years, and only $16 \%$ of patients were older than 15 years. ${ }^{43}$ Patients of the high-risk B-NHL group C (20\% of patients) were featuring with CNS involvement and/or greater than 25\% BM involvement. They received a reduction prephase with $\mathrm{COP}$, two induction courses with COPADM (HDMTX $8 \mathrm{~g} / \mathrm{m}^{2}$ ). Responding patients were randomized to receive two standard consolidation courses with CYVE (high-dose Ara-C, ETO) or two reduced cycles of CYVE. ITC was delivered with high frequency especially in patients with CNS involvement. Treatment concluded in each arm with four alternating maintenance courses (M1-M4). Despite the poor prognosis of this group, the treatment provided 79\% 4-year EFS. Similar to the intermediate group B, most of the patients in this series were children with only $27(11 \%)$ of them older than 15 years. ${ }^{44}$

The United Kingdom Children Cancer Study Group evaluated a therapeutic approach identical to the French LMB 84 protocol in 112 children with stage III or IV B-NHL with up to $70 \%$ FAB L3-type blasts $(n=42)$ in the BM without CNS involvement. The median age was 8.3 years. According to the extent of the primary disease, patients were substaged into three groups: IIIA with unresectable abdominal tumor $(n=39)$; IIIB with abdominal multi-organ involvement $(n=57)$, and IIIX with extra-abdominal primary lymphoma often presenting as pleural effusion $(n=16)$. With a median follow-up of 48 months, OS and EFS were $87 \%$ and $83.7 \%$, respectively. No significant difference in EFS according to the substage at diagnosis could be assessed, making it difficult to identify a group that should not receive intensive therapy. This study confirms the overall good prognosis in children with advanced B-NHL treated with this intensive regimen. ${ }^{45}$

On the other hand, the BFM group tested concurrently short, intensive treatment regimens for B-NHL. Patients were stratified into four risk groups R1, R2, R3, and R4 
comprising approximately $10 \%, 45 \%, 15 \%$, and $30 \%$ of patients, respectively (Table 3). Chemotherapy consisted in 5-day cycle of CPM and prednisone (prephase) followed by 2-6 cycles of 5-day high-dose intensive chemotherapy. The number of cycles was depending on the patient's risk group. Patients were assigned to receive two, four, five, or six courses, based upon dexamethasone, MTX, Ifosfamide, Ara-C, DXR, ETO, and ITC. When compared with the FAB/LMB 96 trial, the major difference was represented by introduction of Ifosfamide and reduction of doses of DXR, CPM, and ETO. Using these regimens, the BFM group recently reported the results of clinical parameters and outcome in 378 adolescent treated in pediatric NHLBFM trials (NHL-BFM 86, NHL-BFM 90, and NHL-BFM 95) stratified according to histological subtype. The 5-year EFS was significantly inferior for adolescents (85\%) when compared with children less than 15 years $(96 \%)$. Results also showed that female sex was associated with a worse prognosis with EFS of $97 \%$ in pediatric boys and $93 \%$ in pediatric girls, but $97 \%$ in adolescent boys and $71 \%$ in adolescent girls. ${ }^{5}$

Other national groups have obtained comparable results using similar strategies. The Italian Association of Pediatric Hematology and Oncology reported a prospective clinical trial including 144 patients aged less than 15 years of whom 39 had DLBCL. The number of courses was stratified according the disease extent, LDH levels, and the tumor mass. The 10-year OS and EFS rates for the overall population were $89.4 \%$ and $81.8 \%$, respectively. The EFS rates for patients in risk groups R1, R2, and R3 were $100 \%, 86.9 \%$, and $75.1 \%$, respectively. Long-term follow-up confirms the observation of a favorable outcome for patients with B-NHL treated with short and intensive chemotherapy regimens. ${ }^{46}$

All these reports mostly concerned children with a median age ranging between 7 and 10 years with almost no patient older than 15 years. ${ }^{39,45,46}$ How and why age $>15$ years could represent an independent adverse prognostic factor remains unknown. High LDH levels, advanced stage, mediastinal disease, and CNS and/or BM involvement at diagnosis also confer an inferior outcome with an increased risk of treatment failure. ${ }^{40}$ High-dose Ara-C and HDMTX clearly improve the outcome of patients with advanced stage and CNS-positive patients. Recent report suggests that not only the dose of MTX, but also the MTX infusion time of 24 hours versus 4 hours positively impact patient's survival. ${ }^{47}$ Moreover, ITC remains important for CNS prophylaxis in young patients with B-NHL.

\section{Adult-like approach}

In the era of new agents, rituximab, a chimeric monoclonal antibody targeting CD20, has dramatically improved adults DLBCL survival when combined to the standard CHOP with a 3 -years OS approximately $60 \%$, in elderly and $79 \%$ in younger patients versus $30 \%$ and $60 \%$ respectively with CHOP alone. ${ }^{48,49}$ Introduction of rituximab in BL patients has demonstrated very encouraging results providing a 5 -year PFS and OS of $71 \%$ and $80 \%$, respectively, and has also shown a high cure rate even in elderly patients with a 5 -year OS of $62 \% .{ }^{50}$ The use of rituximab in pediatric protocols has also been investigated. The ANHL01P1 pilot study demonstrated that addition of rituximab to FAB/ LMB 96 protocols is safe and provides a 3-year EFS of $95 \%$ and $90 \%$ in patients with intermediate risk and high risk, respectively. ${ }^{51,52}$

The German BFM group conducted a phase II window study to examine activity and tolerability of rituximab in newly diagnosed pediatric patients with B-NHL. A single dose of rituximab $\left(375 \mathrm{mg} / \mathrm{m}^{2}\right)$ was administered 1 week before the initiation of frontline BFM chemotherapy. Despite the short observation period of 1 week, $42 \%$ of evaluable patients showed a significant response. ${ }^{53}$ Thus, ongoing trials are currently evaluating the role of rituximab, and try to answer the question whether the addition of rituximab will enable dose reduction of cytotoxic chemotherapy. ${ }^{34}$

To determine whether age is a risk factor in AYA aged 18-35 years treated with CHOP-like regimen, the German High-Grade Non-Hodgkin Lymphoma Study Group (DSHNHL) analyzed outcome of 598 patients treated within 6 prospective phase II and III trials from 1992 to 2008. In all, $71 \%$ of patients were diagnosed with DLBCL, $2 \%$ with BL, and the $28 \%$ remaining patients presented with rarer aggressive lymphoma entities' subtype of B- and T-cell origin. For analysis, patients were stratified into three age groups: 18-25 years, 26-30 years, and 31-35 years. Populations with and without rituximab were analyzed separately. The median age was 28 years. Univariate analysis of EFS and OS with respect of the total population and for treatment with and without rituximab revealed no significant differences among the three age groups. This was also confirmed in multivariate analysis adjusted for aa-IPI, $>1$ extranodal site of involvement, and Bulky disease. The hazard ratios between all age groups were 0.9-1.0 for EFS and 1.1-1.3 for OS, which were not significantly different in all patients and in patients treated with or without rituximab. In the same way, a multivariate analysis showed that the administration of ETO and/or rituximab improved EFS also in AYA population. ${ }^{54}$ 
We recently reported a matched-control analysis of AYA and older patients with large B-cell lymphoma. Fifty-five AYA patients aged 16-30 years were compared with 165 patients aged 31-65 years. Groups were fully matched for IPI, chemotherapy regimen, and rituximab delivery. The AYA patients demonstrated higher rates of mediastinal mass, LDH, and PMBCL subtype. No differences between the two groups were observed in terms of complete remission, and outcome of AYA patients treated with adult's protocols was found to be at least equivalent to that observed in older patients. ${ }^{55}$ So far, the use of more toxic treatments like pediatric protocols remains questionable.

\section{Primary mediastinal B-cell lymphoma}

PMBCL represent a rare subtype of B-cell NHL and typically affects young women. Because prospective studies in PMBCL are few, the choice of optimal treatment is still a matter of debate especially in children and adolescents. Indeed, current standard pediatric regimens are not as effective for PMBCL compared with other pediatric mature B-cell NHLs (BL and DLBCL) treated on similar treatment regimens, and tend to provide worse outcome. Results of the studies are listed in Table 5.
The BFM group reported a series of 30 pediatric patients with PMBCL enrolled in the NHL-BFM trials. Treatment was stratified by stage and LDH value and consisted of four to six 5-day courses of chemotherapy using steroids, alkylating agents, HDMTX, Ara-C, ETO, and DXR. Radiation was not part of the protocol. Median age was 14.3 years (range 1.4-16.7 years). With a median observation time of 5 years (range 1-12 years), probability of 5-year EFS was 70\%. High LDH level was associated with increased risk of failure in multivariate analysis. ${ }^{56}$ In another report of the BFM group, 378 adolescents aged between 15 and 18 years were treated according to pediatric NHL-BFM protocols. The 5-year EFS of patients with PMBCL $(\mathrm{n}=24)$ was at $57 \%$, comparing with $85 \%$ in adolescents with DLBCL. ${ }^{5}$

Another study including 20 patients aged from 4 to 19 years confirmed this less favorable outcome in children and adolescents with mediastinal large cell lymphoma when compared with other localized NHL (5-year EFS at $75 \%$ versus $98 \%)^{57}$

The largest experience of pediatric patients with PMBCL uniformly treated from May 1996 to June 2001 was reported by the cooperative group study FAB/LMB. Childhood and

Table 5 PMBCL selected studies including AYA patients

\begin{tabular}{|c|c|c|c|c|c|c|}
\hline Reference & No of patients & Disease & Age & Treatment & Outcome & Comments \\
\hline $\begin{array}{l}\text { Coso } \\
\text { et } \mathrm{a}^{55} \text { (a) }\end{array}$ & $\begin{array}{l}55 \text { patients } \\
\text { aged } 16-30 \text { years }\end{array}$ & DLBCL/PMBCL & $\begin{array}{l}\text { Median } 26 \\
\text { (range 16-30) }\end{array}$ & $\begin{array}{l}\text { R-CHOP/R- } \\
\text { CHOP-like } \\
\text { ASCT } 58 \%\end{array}$ & $\begin{array}{l}5 \text {-year EFS 68\% } \\
5 \text {-year OS 73\% }\end{array}$ & $\begin{array}{l}33 \% \text { of patients were } \\
\text { diagnosed with } \mathrm{PMBCL}\end{array}$ \\
\hline $\begin{array}{l}\text { Seidemann } \\
\text { et } \mathrm{a}^{56}(\mathrm{p})\end{array}$ & 30 & PMBCL & $\begin{array}{l}\text { Median } 14.3 \\
\text { (range 1.3-16.7) }\end{array}$ & NHL-BFM & 5 -year EFS 70\% & \\
\hline $\begin{array}{l}\text { Gerrard } \\
\text { et a }\left.\right|^{58}(p)\end{array}$ & 42 & PMBCL & $\begin{array}{l}\text { Median } 14.3 \\
\text { (range 1.3-16.7) }\end{array}$ & NHL-BFM & 5-year EFS 70\% & $\begin{array}{l}\text { Treated as intermediate- } \\
\text { risk patients }\end{array}$ \\
\hline $\begin{array}{l}\text { Burkhardt } \\
\text { et al }\left.\right|^{5}(p)\end{array}$ & 24 patients aged $15-18$ & PMBCL & & NHL-BFM & 5-year EFS 57\% & \\
\hline $\begin{array}{l}\text { Lones } \\
\text { et al }\left.\right|^{57}(p)\end{array}$ & 20 & PMBCL & $\begin{array}{l}\text { Median } 12.5 \\
\text { (range 4-19) }\end{array}$ & CCG & $\begin{array}{l}5 \text {-year EFS 75\% } \\
5 \text {-year OS } 85 \%\end{array}$ & \\
\hline $\begin{array}{l}\text { Woessmann } \\
\text { et } \mathrm{al}^{67}(\mathrm{p})\end{array}$ & 15 & PMBCL & $\begin{array}{l}\text { Median } 16 \\
\text { (range II.5-17.8) }\end{array}$ & NHL-BFM & 2-year EFS 92\% & $\begin{array}{l}\text { Treated with R-DA- } \\
\text { EPOCH }\end{array}$ \\
\hline $\begin{array}{l}\text { Rieger } \\
\text { et } \mathrm{al}^{63}(\mathrm{a})\end{array}$ & 44 & PMBCL & $\begin{array}{l}\text { Median } 36 \\
\text { (range 27-43) }\end{array}$ & MinT trial & $\begin{array}{l}3 \text {-year EFS 78\% } \\
3 \text {-year OS 89\% }\end{array}$ & $\begin{array}{l}\text { Subgroup analysis of the } \\
\text { phase III results presented } \\
\text { for R-CHOP arm }\end{array}$ \\
\hline $\begin{array}{l}\text { Dunleavy } \\
\text { et } \mathrm{al}^{66} \text { (a) }\end{array}$ & 51 & PMBCL & $\begin{array}{l}\text { Median } 30 \\
\text { (range 19-52) }\end{array}$ & R-DA-EPOCH & $\begin{array}{l}5 \text {-year EFS } 93 \% \\
5 \text {-year OS } 97 \%\end{array}$ & \\
\hline $\begin{array}{l}\text { Savage } \\
\text { et } \mathrm{al}^{65} \text { (a) }\end{array}$ & $\begin{array}{l}\text { I76 (R-CHOP arm: } \\
96 \text { patients) }\end{array}$ & PMBCL & NA & $\mathrm{R}-\mathrm{CHOP} / \mathrm{CHOP}$ & $\begin{array}{l}5 \text {-year TTP: } 78 \% \\
5 \text {-year OS: } 88 \%\end{array}$ & $\begin{array}{l}\text { Results presented for } \\
\text { R-CHOP arm }\end{array}$ \\
\hline $\begin{array}{l}\text { Vassilakopoulos } \\
\text { et a }\left.\right|^{64} \text { (a) }\end{array}$ & $\begin{array}{l}\text { I2I (R-CHOP arm: } \\
76 \text { patients) }\end{array}$ & PMBCL & 31.5 & R-CHOP/CHOP & $\begin{array}{l}5 \text {-year FFP: } 81 \% \\
5 \text {-year OS: } 89 \%\end{array}$ & $\begin{array}{l}\text { Results presented for } \\
\text { R-CHOP arm }\end{array}$ \\
\hline $\begin{array}{l}\text { Martelli } \\
\text { et } \mathrm{al}^{36}(\mathrm{a})\end{array}$ & $\begin{array}{l}\text { I } 25 \text { (54 patients } \\
\text { with FDG-PET/CT CMR) }\end{array}$ & PMBCL & 33 & $\begin{array}{l}\text { R-CHOP/R- } \\
\text { CHOP-like }\end{array}$ & $\begin{array}{l}5 \text {-year EFS } 98 \% \\
5 \text {-year OS } 100 \%\end{array}$ & $\begin{array}{l}\text { Results presented for } \\
\text { patients with FDG-PET/ } \\
\text { CT CMR }\end{array}$ \\
\hline
\end{tabular}

Notes: (p): pediatric oncology study group; (a): adult's oncology study group.

Abbreviations: AYA, adolescents and young adults; ASCT, autologous stem cell transplantation; BFM, Berlin-Frankfurt-Munster; CMR, complete metabolic response; CT, computed tomography; DLBCL, diffuse large B-cell lymphoma; EFS, event-free survival; FDG-PET, F-fluorodeoxyglucose-positron emission tomography; FFP, freedom from progression; NA, not available; NHL, Non-Hodgkin lymphomas; OS, overall survival; PMBCL, primary mediastinal B-cell lymphoma; R-CHOP, rituximab, cyclophosphamide, doxorubicin, vincristine, and prednisone; R-DA-EPOCH, dose-adjusted rituximab, etoposide, prednisone, vincristine, cyclophosphamide, and doxorubicin; TTP, time from treatment progression. 
adolescent patients with stage III PMBCL (42) and nonPMBCL DLBCL (69) were treated with the Group B therapy in the FAB/LMB 96 study. Patients with PMBCL had a median age at 15.7 years (range 12.5-19.7). Five-year EFS for the PMBCL and non-PMBCL DLBCL groups was $66 \%$ and $85 \%$, respectively $(P<0.001)$. Authors concluded that PMBCL in adolescent patients is associated with significantly inferior EFS compared with non-PMBCL DLBCL. ${ }^{58}$

Treatment of PMBCL in AYA is of considerable interest because young patients with PMBCL tend to have a worse outcome than those with DLBCL. In the same time, recent improvements in the treatment of adult PMBCL have been achieved.

Various chemotherapy regimens, such as MACOP-B and VACOP-B (etoposide, doxorubicine, cyclophosphamide, vincristine, prednisone, bleomycin), have been studied in adult patients with PMBCL, resulting in a survival benefit over conventional CHOP therapy. ${ }^{59-61}$ In addition, early intensification treatment integrating chemotherapy, autologous stem cell transplantation, and radiotherapy (RT) has been tested in a small series of adult patients with poor-risk PMBCL, leading to a $93 \%$ disease-free survival rate after 35 months median follow-up. ${ }^{62}$

The PMBCL entity has been recently explored in the era of rituximab. The Mabthera International Trial group evaluated the impact of CHOP-like chemotherapy and rituximab in 87 adult patients (median age 36 years) with PMBCL. Results showed a 3-year EFS and OS at 78\% and $89 \%$, respectively. ${ }^{63}$

In a retrospective study, 76 consecutive PMBCL patients who received R-CHOP with or without RT were compared with 45 consecutive historical patients treated with CHOP with or without RT. Patients treated with R-CHOP had a significantly superior 5-year freedom from progression rate of $81 \%$ versus $48 \%$ for those treated with CHOP. Radiation therapy is routinely included as a part of initial therapy and its role has been also assessed. Most of the patients treated with R-CHOP received RT (76\%), whereas only $48 \%$ of patients treated with CHOP were consolidated by RT. Results showed that in the group of responder patients, administration of RT was not associated with any freedom from progression or OS benefit. ${ }^{64}$

Another report evaluated the benefits of consolidative RT after (R)-CHOP regimen in patients with PMBCL. In this retrospective study, RT was FDG-PET/CT guided, and only patients with FDG-PET/CT positive at the end of treatment were considered for RT. With a median follow-up of 5 years, there was no difference in OS between FDG-PET/CT-positive and FDG-PE/CT-negative patients, suggesting that a FDG-
PET/CT-guided RT approach may reduce the use of RT while maintaining good outcomes. ${ }^{65}$

A recent large prospective study conducted in 125 patients assessed the place of FDG-PET/CT at the completion of treatment. Complete metabolic response (CMR) after chemo-immunotherapy was reported for $47 \%$ of patients and conferred 98\% 5-year PFS. Most patients (92\%) and the majority of patients in CMR (89\%) received consolidative RT. The excellent outcome especially for patients reaching CMR suggests that it should be possible to safely avoid RT. ${ }^{36}$ Further prospective studies are required to establish the role of consolidative RT in PMBCL patients.

The most relevant study in the treatment of patients with PMBCL has been recently reported by Dunleavy et al. They conducted a phase 2 prospective study of infusional dose-adjusted ETO, DXR, and CPM with VCR, prednisone, and rituximab (DA-EPOCH-R) without RT, in 51 patients with untreated primary mediastinal B-cell lymphoma. The patients had a median age of 30 years (range 19-52). With a median follow-up of 5 years, the EFS rate was $93 \%$ and the OS rate was $97 \%$. With a follow-up ranging from 10 months to 14 years, all but 2 of the 51 patients (4\%) who received DA-EPOCH-R without RT were in continuous complete remission. The two remaining patients received RT and were disease free at follow-up. No late morbidity or cardiac toxic effects were found in any patient. Authors concluded that DA-EPOCH-R provides a high cure rate and obviated the need for RT in adult patients with PMBCL. ${ }^{66}$

An international trial in children with PBMCL has been initiated and preliminary results are encouraging. Woessmann et al reported the outcome of 15 young PMBCL patients with a median age of 16 years (range 11.5-17.8) who received the DA-EPOCH-R regimen. With a median follow-up of 19.2 months (range 9.6-28.8), both the mean EFS and OS rates at 2 years were $92 \%$. This observation confirms the efficacy of DA-EPOCH-R in the treatment of primary mediastinal large-B-cell lymphoma in children, adolescents, and young adults. ${ }^{67}$

In most of reported series, PMBCL patients are older than 30 years, and no data are available for younger patients when treated with adult approach. Nevertheless, we recently demonstrated that AYA patients with PMBCL showed a favorable outcome with a 5-year EFS and OS at 73\% and $76 \%$, respectively, after receiving a chemotherapy regimen including rituximab. ${ }^{55}$

\section{Conclusion}

In this review, we highlighted several epidemiological, biological, and clinical aspects, prognostic factors, and outcome 
after treatment in AYA with B-NHL and especially DLBCL and PMBCL. Several points can be raised regarding future objectives we have to reach for a better understanding of these diseases in this young population. ${ }^{68}$ Unlike adult population, the prognostic indexes usually used to stratify risk patients are not satisfactory. Biological markers and new imaging techniques such as PET scan will help us to better stratify patients in the future. Concerning treatment guidelines, we need prospective trials designed specifically for this population. In fact, therapeutic regimens often depend on the site of treatment and the referring physician, with some patients receiving pediatric protocols and others treated with adult rituximab-based chemotherapy. This review also demonstrates that all AYA with B-NHL do not have a similar outcome after treatment. Age definitely represents an adverse factor. Thus, if patients aged from 20 to 30 years seemed to benefit from adult's protocol, younger patients aged from 15 to 20 years have a worse outcome even when they receive pediatric protocols. Therefore, it is crucial to better identify biological features that are characteristic of lymphoma in AYA in order to address more tailored treatments and especially new targeted therapies. For this purpose, future trials should focus on this group of patients, and a narrow collaboration between adult and pediatric hematologists should be effective. Adolescence remains a critical age and adherence of patients to treatments is often complicated. Collaborative efforts focusing on therapeutic interventions but also psychological and social aspects are highly recommended for the future.

\section{Disclosure}

The authors report no conflicts of interest in this work.

\section{References}

1. Bleyer A, O'Leary M, Barr R. Cancer epidemiology in older adolescents and young adults 15 to 29 years of age, including SEER incidence and survival: 1975-2000. Bethesda, MD: National Cancer Institute; 2006.

2. Bleyer A, Viny A, Barr R. Cancer in 15- to 29-year-olds by primary site. Oncologist. 2006;11(6):590-601.

3. Hochberg J, Waxman IM, Kelly KM, Morris E, Cairo MS. Adolescent non-Hodgkin lymphoma and Hodgkin lymphoma: state of the science. Br J Haematol. 2009; 144(1):24-40.

4. Patte C, Auperin A, Sebban C, et al. The 15-20 year old patients with NHL treated in France: data of childhood and adult database (abstract 85). Ann Oncol. 2005;16(Suppl 5):61.

5. Burkhardt B, Oschlies I, Klapper W, et al. Non-Hodgkin's lymphoma in adolescents: experiences in 378 adolescent NHL patients treated according to pediatric NHL-BFM protocols. Leukemia. 2011;25(1): 153-160.

6. Clarke CA, Glaser SL. Changing incidence of non-Hodgkin lymphomas in the United States. Cancer. 2002;94(7):2015-2023.

7. Jaglowski SM, Linden E, Termuhlen AM, Flynn JM. Lymphoma in adolescents and young adults. Semin Oncol. 2009;36(5):381-418.
8. Patte C, Auperin A, Michon J, et al. The Société Française d'Oncologie Pédiatrique LMB89 protocol: highly effective multiagent chemotherapy tailored to the tumor burden and initial response in 561 unselected children with B-cell lymphomas and L3 leukemia. Blood. 2001;97(11):3370-3379.

9. Burkhardt B, Zimmermann M, Oschlies I, et al. The impact of age and gender on biology, clinical features and treatment outcome of nonHodgkin lymphoma in childhood and adolescence. $\mathrm{Br} J$ Haematol. 2005;131(1):39-49.

10. Albritton K, Bleyer WA. The management of cancer in the older adolescent. Eur J Cancer. 2003;39(18):2584-2599.

11. Boissel N, Auclerc M-F, Lhéritier V, et al. Should adolescents with acute lymphoblastic leukemia be treated as old children or young adults? Comparison of the French FRALLE-93 and LALA-94 trials. J Clin Oncol. 2003;21(5):774-780.

12. Ramanujachar R, Richards S, Hann I, et al. Adolescents with acute lymphoblastic leukaemia: outcome on UK national paediatric (ALL97) and adult (UKALLXII/E2993) trials. Pediatr Blood Cancer. 2007;48(3):254-261.

13. Stock W, La M, Sanford B, et al. What determines the outcomes for adolescents and young adults with acute lymphoblastic leukemia treated on cooperative group protocols? A comparison of Children's Cancer Group and Cancer and Leukemia Group B studies. Blood. 2008; 112(5):1646-1654.

14. Jaffe E, Harris N, Stein H, Vardiman J. World Health Organization classification of tumors. Tumors of haematopoietic and lymphoid tissues. Washington, DC: IARC Press; 2000.

15. Reiter A, Klapper W. Recent advances in the understanding and management of diffuse large B-cell lymphoma in children. $\mathrm{Br} J$ Haematol. 2008;142(3):329-347.

16. Campo E, Swerdlow SH, Harris NL, Pileri S, Stein H, Jaffe ES. The 2008 WHO classification of lymphoid neoplasms and beyond: evolving concepts and practical applications. Blood. 2011;117(19):5019-5032.

17. Swerdlow SH, Campo E, Harris N, Jaffe E, Pileri S, Stein H. WHO classification of tumors of the haematopoietic and lymphoid tissues. Lyon: IARC; 2008.

18. Alizadeh AA, Eisen MB, Davis RE, et al. Distinct types of diffuse large B-cell lymphoma identified by gene expression profiling. Nature. 2000;403(6769):503-511.

19. Rosenwald A, Wright G, Chan WC, et al. The use of molecular profiling to predict survival after chemotherapy for diffuse large-B-cell lymphoma. N Engl J Med. 2002;346(25):1937-1947.

20. Rosenwald A, Wright G, Leroy K, et al. Molecular diagnosis of primary mediastinal B cell lymphoma identifies a clinically favorable subgroup of diffuse large B cell lymphoma related to Hodgkin lymphoma. J Exp Med. 2003;198(6):851-862.

21. Savage KJ, Monti S, Kutok JL, et al. The molecular signature of mediastinal large B-cell lymphoma differs from that of other diffuse large B-cell lymphomas and shares features with classical Hodgkin lymphoma. Blood. 2003;102(12):3871-3879.

22. Hans CP, Weisenburger DD, Greiner TC, et al. Confirmation of the molecular classification of diffuse large B-cell lymphoma by immunohistochemistry using a tissue microarray. Blood. 2004;103(1): 275-282.

23. Oschlies I, Klapper W, Zimmermann M, et al. Diffuse large B-cell lymphoma in pediatric patients belongs predominantly to the germinalcenter type B-cell lymphomas: a clinicopathologic analysis of cases included in the German BFM (Berlin-Frankfurt-Munster) Multicenter Trial. Blood. 2006;107(10):4047-4052.

24. Salaverria I, Philipp C, Oschlies I, et al. Translocations activating IRF4 identify a subtype of germinal center-derived B-cell lymphoma affecting predominantly children and young adults. Blood. 2011;118(1): 139-147.

25. Hummel M, Bentink S, Berger H, et al. A biologic definition of Burkitt's lymphoma from transcriptional and genomic profiling. $N$ Engl $J$ Med. 2006;354(23):2419-2430. 
26. Dave SS, Fu K, Wright GW, et al. Molecular diagnosis of Burkitt's lymphoma. N Engl J Med. 2006;354(23):2431-2442.

27. Klapper W, Szczepanowski M, Burkhardt B, et al. Molecular profiling of pediatric mature B-cell lymphoma treated in population-based prospective clinical trials. Blood. 2008;112(4):1374-1381.

28. Friedberg JW. Double-hit diffuse large B-cell lymphoma. J Clin Oncol. 2012;30(28):3439-3443.

29. Barrans S, Crouch S, Smith A, et al. Rearrangement of MYC is associated with poor prognosis in patients with diffuse large B-cell lymphoma treated in the era of rituximab. J Clin Oncol. 2010;28(20):3360-3365.

30. Deffenbacher KE, Iqbal J, Sanger W, et al. Molecular distinctions between pediatric and adult mature B-cell non-Hodgkin lymphomas identified through genomic profiling. Blood. 2012;119(16):3757-3766.

31. Lange J, Burkhardt B. Treatment of adolescents with aggressive B-cell malignancies: the pediatric experience. Curr Hematol Malig Rep. 2013;8(3):226-235.

32. Pileri SA, Gaidano G, Zinzani PL, et al. Primary mediastinal B-cell lymphoma: high frequency of BCL-6 mutations and consistent expression of the transcription factors OCT-2, BOB.1, and PU.1 in the absence of immunoglobulins. Am J Pathol. 2003;162(1):243-253.

33. Oschlies I, Burkhardt B, Salaverria I, et al. Clinical, pathological and genetic features of primary mediastinal large B-cell lymphomas and mediastinal gray zone lymphomas in children. Haematologica. 2011;96(2):262-268

34. El-Mallawany NK, Cairo MS. Advances in the diagnosis and treatment of childhood and adolescent B-cell non-Hodgkin lymphoma. Clin Adv Hematol Oncol. 2015;13(2):113-123.

35. Cheson BD, Fisher RI, Barrington SF, et al. Recommendations for initial evaluation, staging, and response assessment of Hodgkin and non-Hodgkin lymphoma: the Lugano classification. J Clin Oncol. 2014;32(27):3059-3068.

36. Martelli M, Ceriani L, Zucca E, et al. [18F]fluorodeoxyglucose positron emission tomography predicts survival after chemoimmunotherapy for primary mediastinal large B-cell lymphoma: results of the International Extranodal Lymphoma Study Group IELSG-26 Study. J Clin Oncol. 2014;32(17):1769-1775.

37. Murphy SB. Classification, staging and end results of treatment of childhood non-Hodgkin's lymphomas: dissimilarities from lymphomas in adults. Semin Oncol. 1980;7(3):332-339.

38. Carbone PP, Kaplan HS, Musshoff K, Smithers DW, Tubiana M. Report of the Committee on Hodgkin's Disease Staging Classification. Cancer Res. 1971;31(11):1860-1861.

39. Reiter A, Schrappe M, Tiemann M, et al. Improved treatment results in childhood B-cell neoplasms with tailored intensification of therapy: a report of the Berlin-Frankfurt-Münster Group Trial NHL-BFM 90. Blood. 1999;94(10):3294-3306.

40. Cairo MS, Sposto R, Gerrard M, et al. Advanced stage, increased lactate dehydrogenase, and primary site, but not adolescent age ( $\geq 15$ years), are associated with an increased risk of treatment failure in children and adolescents with mature B-cell non-Hodgkin's lymphoma: results of the FAB LMB 96 study. J Clin Oncol. 2012;30(4):387-393.

41. No author. A predictive model for aggressive non-Hodgkin's lymphoma. The International Non-Hodgkin's Lymphoma Prognostic Factors Project. N Engl J Med. 1993;329(14):987-994.

42. Gerrard M, Cairo MS, Weston C, et al. Excellent survival following two courses of COPAD chemotherapy in children and adolescents with resected localized B-cell non-Hodgkin's lymphoma: results of the FAB/ LMB 96 international study. Br J Haematol. 2008;141(6):840-847.

43. Patte C, Auperin A, Gerrard M, et al. Results of the randomized international FAB/LMB96 trial for intermediate risk B-cell non-Hodgkin lymphoma in children and adolescents: it is possible to reduce treatment for the early responding patients. Blood. 2007;109(7):2773-2780.

44. Cairo MS, Gerrard M, Sposto R, et al. Results of a randomized international study of high-risk central nervous system $B$ non-Hodgkin lymphoma and B acute lymphoblastic leukemia in children and adolescents. Blood. 2007;109(7):2736-2743.
45. Atra A, Imeson JD, Hobson R, et al. Improved outcome in children with advanced stage B-cell non-Hodgkin's lymphoma (B-NHL): results of the United Kingdom Children Cancer Study Group (UKCCSG) 9002 protocol. Br J Cancer. 2000;82(8):1396-1402.

46. Pillon M, Di Tullio MT, Garaventa A, et al. Long-term results of the first Italian Association of Pediatric Hematology and Oncology protocol for the treatment of pediatric B-cell non-Hodgkin lymphoma (AIEOP LNH92). Cancer. 2004;101(2):385-394.

47. Woessmann W, Seidemann K, Mann G, et al. The impact of the methotrexate administration schedule and dose in the treatment of children and adolescents with B-cell neoplasms: a report of the BFM Group Study NHL-BFM95. Blood. 2005;105(3):948-958.

48. Coiffier B, Lepage E, Briere, et al. CHOP chemotherapy plus rituximab compared with CHOP alone in elderly patients with diffuse large-B-cell lymphoma. N Engl J Med. 2002;346(4):235-242.

49. Pfreundschuh M, Trümper L, Osterborg A, et al. CHOP-like chemotherapy plus rituximab versus CHOP-like chemotherapy alone in young patients with good-prognosis diffuse large-B-cell lymphoma: a randomised controlled trial by the MabThera International Trial (MInT) Group. Lancet Oncol. 2006;7(5):379-391.

50. Hoelzer D, Walewski J, Döhner H, et al. Improved outcome of adult Burkitt lymphoma/leukemia with rituximab and chemotherapy: report of a large prospective multicenter trial. Blood. 2014;124(26): 3870-3879.

51. Goldman S, Smith L, Anderson JR, et al. Rituximab and FAB/LMB 96 chemotherapy in children with Stage III/IV B-cell non-Hodgkin lymphoma: a Children's Oncology Group report. Leukemia. 2013;27(5): 1174-1177.

52. Goldman S, Smith L, Galardy P, et al. Rituximab with chemotherapy in children and adolescents with central nervous system and/or bone marrow-positive Burkitt lymphoma/leukaemia: a Children's Oncology Group Report. Br J Haematol. 2014;167(3):394-401.

53. Meinhardt A, Burkhardt B, Zimmermann M, et al. Phase II window study on rituximab in newly diagnosed pediatric mature B-cell nonHodgkin's lymphoma and Burkitt leukemia. J Clin Oncol. 2010;28(19): 3115-3121.

54. Hohloch K, Zeynalova S, Held G, et al. Excellent outcome of young adults with aggressive non-Hodgkin lymphomas treated with CHOPlike regimens. Leukemia. 2014;28(11):2260-2263.

55. Coso D, Garciaz S, Esterni B, et al. Large B-cell lymphomas in adolescents and young adults in comparison to adult patients: a matched-control analysis in 55 patients. Leuk Lymphoma. 2014;55(8): 1849-1853.

56. Seidemann K, Tiemann M, Lauterbach I, et al. Primary mediastinal large B-cell lymphoma with sclerosis in pediatric and adolescent patients: treatment and results from three therapeutic studies of the Berlin-Frankfurt-Münster Group. J Clin Oncol. 2003;21(9): $1782-1789$.

57. Lones MA, Perkins SL, Sposto R, et al. Large-cell lymphoma arising in the mediastinum in children and adolescents is associated with an excellent outcome: a Children's Cancer Group report. J Clin Oncol. 2000;18(22):3845-3853.

58. Gerrard M, Waxman IM, Sposto R, et al. Outcome and pathologic classification of children and adolescents with mediastinal large B-cell lymphoma treated with FAB/LMB96 mature B-NHL therapy. Blood. 2013;121(2):278-285.

59. Rodríguez J, Gutiérrez A, Piris M. Primary mediastinal B-cell lymphoma: treatment and therapeutic targets. Leuk Lymphoma. 2008;49(6):1050-1061.

60. Todeschini G, Secchi S, Morra E, et al. Primary mediastinal large B-cell lymphoma (PMLBCL): long-term results from a retrospective multicentre Italian experience in 138 patients treated with CHOP or MACOP-B/VACOP-B. Br J Cancer. 2004;90(2):372-376.

61. Savage KJ, Al-Rajhi N, Voss N, et al. Favorable outcome of primary mediastinal large B-cell lymphoma in a single institution: the British Columbia experience. Ann Oncol. 2006;17(1):123-130. 
62. Cairoli R, Grillo G, Tedeschi A, et al. Efficacy of an early intensification treatment integrating chemotherapy, autologous stem cell transplantation and radiotherapy for poor risk primary mediastinal large B cell lymphoma with sclerosis. Bone Marrow Transplant. 2002;29(6):473-477.

63. Rieger M, Osterborg A, Pettengell R, et al. Primary mediastinal B-cell lymphoma treated with CHOP-like chemotherapy with or without rituximab: results of the Mabthera International Trial Group study. Ann Oncol. 2011;22(3):664-670.

64. Vassilakopoulos TP, Pangalis GA, Katsigiannis A, et al. Rituximab, cyclophosphamide, doxorubicin, vincristine, and prednisone with or without radiotherapy in primary mediastinal large B-cell lymphoma: the emerging standard of care. Oncologist. 2012;17(2):239-249.
65. Savage KJ, Yenson PR, Shenkier T, et al. The outcome of primary mediastinal large B-cell lymphoma (PMBCL) in the R-CHOP treatment era. Blood (ASH Annual Meeting Abstracts). 2012;120(21):303.

66. Dunleavy K, Pittaluga S, Maeda LS, et al. Dose-adjusted EPOCHrituximab therapy in primary mediastinal B-cell lymphoma. $N$ Engl J Med. 2013;368(15):1408-1416.

67. Woessmann W, Lisfeld J, Burkhardt B, NHL-BFM Study Group. Therapy in primary mediastinal B-cell lymphoma. N Engl J Med. 2013; 369(3):282.

68. Wolach O, Ram R. Adolescents and young adults with non-Hodgkin's lymphoma: slipping between the cracks. Acta Haematol. 2014; 132(3-4):279-291.
Clinical Oncology in Adolescents and Young Adults

\section{Publish your work in this journal}

Clinical Oncology in Adolescents and Young Adults is an international, peer-reviewed, open access journal publishing original research, reports, editorials, reviews and commentaries on all aspects of epidemiology, diagnosis and treatment of cancers in adolescents and young adults. The manuscript management system is completely

\section{Dovepress}

online and includes a very quick and fair peer-review system. Visit http://www.dovepress.com/testimonials.php to read real quotes from published authors.

\footnotetext{
Submit your manuscript here: http://www.dovepress.com/clinical-oncology-in-adolescents-and-young-adults-journal
} 